\title{
Language and Power in Cross River State, Nigeria
}

\author{
Mercy Ugot, Ph.D \\ Department of Language and Linguistic Science \\ Cross River University of Technology, Calabar, Cross River State Nigeria \\ E-mail: mercyugot@yahoo.com \\ Mathew Nsing Ogar, Ph.D \\ Department of Curriculum and Instructional Technology \\ Cross River University of Technology, Calabar, Nigeria \\ Email: ogarnsing67@yahoo.com
}

\section{Doi:10.5901/mjss.2014.v5n10p648}

\section{Abstract}

This work focuses on the languages of Cross River State and their relative relevance in the state. Cross River State is a multilingual state with many of Nigeria's minority languages to be found within it. The paper examines the relative status and functions of the languages in use in the state and their relevance to affairs of the state. The languages have been seen to be state languages, Local Government Area (LGA) languages while others do not have any functional status. Coupled with other non-indigenous languages in the state, some languages are official; others are second languages, lingua francas, trade languages etc. in importance. They are used in the domain of administration, politics, education, trade etc. in the state. For the other indigenous languages in particular, it is suggested that though they are not state languages and are not in use outside of their immediate environment, they should be developed in order to maintain the identity and history of the people.

Keyword: Language, power, multilingualism, language policy

\section{Introduction}

Cross River State is one of the 36 states of the Federal Republic of Nigeria and located within the South-South geopolitical zone of Nigeria. It covers an area totaling 21,481 square kilometers, with a population density of about 65 persons per square kilometer. The total population from the 2006 census is 2,888,966 m (Nigeria 2006 Census Figures) 1,492,465 males and 1,396,501 female (Udoh 2003). Historically, the state was one of Nigeria's earliest ports, which began even before the colonial period. Calabar, its capital was the first capital of Southern Nigeria. (Peters 2000).

Cross River State as part of the Nigerian Federation was first created in May 27, 1967. The state was then called the South-Eastern State, and it was made up of Calabar, Ogoja, Uyo and Anaang provinces. The name of the state was changed to Cross River State in 1967, after the Cross River, following the decision to name the states of the Nigerian Federation after physical features like rivers.

When Akwa-lbom State was carved out of it in 1987, the state was left with seven LGAs. Today it has eighteen Local Government Area (LGAs) with the distribution given in Table 1.

\section{Literature Review}

According to Crystal (2003) language at its most specific level, may refer to the concrete act of speaking, writing or signing in a given situation-the notion of parole or performance. McGregor (2009) says human language is a particularly elaborate sign system that has properties not manifested or weakly manifested in other sign systems. These features include arbitrariness, displacement, cultural transmission, duality, productivity and reflexitivity. Chomsky \& Halle (1968) define language as a set of sentences each with an ideal form and an associated intrinsic and semantic interpretation. Sapir (1921:8) who popularized the hypothesis of linguistic determinism and linguistic relativity defines language as "purely human and non-instinctive method of communication of ideas, emotions and desires by voluntary produced symbols".

Essien (2003) defines power as strength, might, ability to compel an individual or an institution to do what it would 
not like to do. Power, therefore can be political, educational, cultural, physical, social, sexual, religious, spiritual etc. In this work power is viewed along a continuum of weak to strong to strongest.

Language is a cognitive system, biologically represented in the brain and the brain is the center of man himself and language, the very essence of man's humanity is as essential and powerful as the very source of it, the brain. The power of language can be seen in its use of persuasion and propaganda. According to Enoh (2013) power lies in the use of force to achieve an end. Thus power is "the ability to get ones wishes carried out despite opposition" (Wiseman, 1966:25) or "against the will or desire of another" (Wasby, 1972).

Essien (2003) posits that because European nations knew the power and potentials of language, multilingual European nations often respected linguistic sensitivities. One way Europe has been able to manage its multilingualism without sacrificing too much is the principle of what has come to be known as language right which has come through national independence granted to some ethnic minorities. Deutshe (1968) as cited by Wardhaugh (1986) has documented the tremendous increase within Europe during the last 1,000 years counting from 1968 backwards of what he calls "full-fledged" languages.

From only 6 languages in A.D 950-Latin, Greek, Hebrew, Arabic, Old English and church salvonic, there were over 53 "full fledged" official national languages by 1937. The number has obviously increased since then such that what used to be ethnic languages like Czech and Slovak are now "full-fledged" national languages (Essien 2003).

Each new nation had a new national and official language and such a language became a basic expression of the identity and aspiration of the people and government. Language planning was embarked on such that"...government authorized long term sustained and conscious efforts to alter a language" (Weinstein 1980:56). From these new nations of Europe, economic, legal, socio-cultural and linguistic developments are crucial in national development.

Essien (2003b) gives the interplay of power arising from the dichotomy between majority and minority languages. Minority and majority languages have been viewed from the perspective of demography or number of speakers and the denomination or power of language in a given community. From a global view point Skutnabb-Kangas (1990:) sees linguistic minority and majority in terms of power relationship not in terms of numerical strength (though the two sometimes coincide).

Skutnabb-Kangas (1990) postulates that

\begin{abstract}
...if a 'majority' is used to refer to a numerical strong but politically weak group (like in the blacks in South Africa) this is marked by calling them a 'powerless' majority, implying that they have the capacity and resources to become a 'real' majority (i.e. get access by their fair share of power and resources). Several minorities which together form a numerical majority and have approximately equal status when compared with each other can also be seen as a majority. Groups like the white groups in South Africa which is numerically a minority, but in terms of power a majority can be marked by calling it a powerful minority.
\end{abstract}

By this definition, the English language spoken in Nigeria by small ethnic elites in the country is markedly a powerful minority language given its status as a dominant language in the country and its 36 states.

Put more simply a language spoken by a relatively small number of people may become powerful and dominant because of the people who speak it. Powerful native speakers of a language are powerful in every sense of the word. They invest their language with power and prestige. On the other hand, poor and unaccomplished people, no matter how numerous, may do very little to uplift their language (Essien 2003a).

Garry and Rubino (2001) see a majority language primarily in terms of numerical strength. For them, language spoken by 2 million people or more is a world major language, regardless of the achievement by the speakers. The concepts of majority and minority are often shifting-determined by each linguistic community and in which speakers find themselves (e.g. a nation state in a Federal set-up etc). Therefore, a language may be a minority in one setting, but a majority in another. For example, Lokaa spoken in Yakurr LGA is a minority language in Cross River State but a major language in Yakurr LGA, and while Hausa is a minority language in Ghana, in Nigeria, it is clearly a major language (Bamgbose 1992).

Essien (2003) asserts that a dominant language

...in a bilingual or multi lingual setting, there is usually one language, regardless of its size, which invests its users not only with what Wardhaugh (1986:344) refers to as "the full-panoply of users that signify a standard language" but also with prestige, self-confidence and power.

By power here is meant economic, educational, academic, intellectual, socio-cultural and political powers. In Nigeria and by extension Cross River State the language that takes on this role is English, often referred to as the exo- 
glossic language. The other languages have power or dominance in varying degrees such as the dominance of Hausa in the North, Yoruba in the South-West and Igbo in the South-East.

If Hausa, Yoruba and Igbo are 3 major languages in Nigeria with varying degrees of power and dominance there are other categories of languages variously classified as main, minority, minor and small group by Bamgbose (1992); millionaire, centimil and minority/ local by Brann (1986); second class, third class and fourth class by Olagoke (1982); and medium, minor and micro-minority by Essien (2003b). These classifications correspond not only to the sizes of the languages but also to respective dominance and power. Bamgbose (1992) notes the change in status of some languages because of creation and recreation of states. Some minority languages have attained a dominant status. We shall examine this through the language typologies to be found in Cross River State.

\section{The Linguistic Situation in Cross River State}

\subsection{The Indigenous Languages}

The languages of Cross River State are spoken in 18 Local Government Areas (LGAs) of the state as distributed in table 1. Udoh (2003) says the LGA boundaries do not exactly correspond to ethnic groups, such that there are very few linguistically homogenous LGAs. The heterogeneous LGAs are Abi, Akamkpa, Biase, Ikom, Obanliku Calabar Municipality, Obudu, Odukpani, Ogoja and Yakurr LGA's. The homogenous LGAs are Calabar South, Akpabuyo, Bakassi, Bekwarra, Boki, Etung, Obubra and Yala.

There are 37 languages with a network of dialects and language clusters. It is therefore a fairly complicated linguistic situation. All the languages spoken in Cross River State fall within the Benue-Congo sub-family of the NigerCongo phylum.

Table 1: The language of Cross River State

\begin{tabular}{|c|l|l|c|l|}
\hline S/N & LGA & H/Qtrs & Population & Languages/Dialects \\
\hline 1. & Abi & Itigidi & 144,802 & Leggbo, Bahumono \\
\hline 2. & Akamkpa & Akamkpa & 151,125 & Efik, Ejagham, Korop, Ukwa, Ito, Derop \\
\hline 3. & Akpabuyo & Ikot-Nakanda & 144,802 & Efik \\
\hline 4. & Bakassi & Abana & 32,385 & Efik \\
\hline 5. & Bekwarra & Abochiche & 105,822 & Bekwarra, Afrike \\
\hline 6. & Biase & Akpet Central & 169,183 & Nne, Mehu, Ubaghara, Umon, Isanginyoinyo, Iyoniyong \\
\hline 7. & Boki & Boje & 186,141 & Bokyi \\
\hline 8. & Calabar municipality & Calabar & 179,392 & Efik, Ejagham \\
\hline 9. & Calabar south & Anantigha & 191,630 & Efut, Efik \\
\hline 10. & Etung & Efraya & 80,196 & Ejagham \\
\hline 11. & Ikom & Ikom & 162,383 & Olulumo, Ikom, Ejagham, Bakor, Mbembe, Yala Nkum \\
\hline 12. & Obanliku & Sankwala & 110,324 & Obanliku, Bendi \\
\hline 13. & Obubra & Obubra & 172,444 & Mbembe \\
\hline 14. & Obudu & Obudu & 160,106 & Bette, Alege, Utugwang, Ukpe, Ubang, Okworotung, Mgbenege \\
\hline 15. & Odukpani & Odukpani & 192,444 & Ejagham, Efik, Odot, Kiong \\
\hline 16. & Ogoja & Ogoja & 171,901 & Ishibori, Ekajuk, Mbube \\
\hline 17. & Yakurr & Ugep & 196,450 & Lokaa, Nko, Leggbo \\
\hline 18. & Yala & Okpoma & 210,843 & Yala, Yache, Kukelle \\
\hline
\end{tabular}

Source: National Population Commission, 2006 Population Census and Udoh 2003. 54 - 60.

According to Crozier \& Blench (1992) three of the twelve listed major sub-groups are represented adequately, namely, the Idomoid, the Cross River and the Bantoid. Of all three, Cross River, made up of Bendi and Delta Cross together, constitute the largest number of languages spoken in Cross River State. The languages of Cross River Sate are further subdivided into the Lower Cross languages, the Upper Cross languages and the Bantoid languages. These are Efik, Ukwa and Ito in the south for the Lower Cross, while the Upper Cross group dominates with several languages centrally. Further up north are the Bantoid group of languages.

Within the definition of minority and majority languages in Nigeria, the languages of Cross River State are minority languages based on demographic indices. Some of the languages such as Agwagune (of the Nne group), Lokaa, Yala, Mbembe have been raised in status since the creation of state to LGA language based again on the number of speakers 
in the LGA.

Apart from the indigenous languages, other languages spoken in the state include the English language and its variant of Nigerian English (NE) and the Nigerian Pidgin (NP).

\subsection{The English Language}

This is Nigeria's official language and by extension, the official language of Cross River State. The language is used in administration, trade, in education as a medium of instruction, in politics and for social interaction. Although the English language is also a second language in Nigeria, it is more powerful than any of the indigenous languages as it is associated with attainment of personal and group goals unattainable by means of the native languages. To speak 'good' English is a symbol of one's education and status in the society (Jowitt 1991). The English language therefore has farreaching social consequences, especially for the less powerful languages of Cross River State, where many ethnolinguistic groups exist in unequal relationship (Essien, 2003).

\subsection{The Nigerian Pidgin (NP)}

Abdullahi-Idiagbon (2007) asserts, that the NP actually started as a contingency language between white merchants, who later turned colonial 'masters' and their black traders. The NP in Nigeria is made up of several variants which are characterized by a preponderant influence of its substrate language on the form and usage of that variant. There are two variants spoken in Cross River State and these are Calabar variant and the Ikom-Ogoja variant (Ugot \& Offiong 2013). These variants are popularized by their vocabularies from the substrate language including their pronunciation, spelling, usage and meaning beyond the territory by the original speakers. Jowitt (1991) observes that NP has attained the feat of dignity not only among the illiterate but also the literate members of society. Adegbija (1994) also notes the utility and elevation of NP and cites its grassroot popularity and cultural neutrality and usage.

In Cross River State, the growth and usage of NP is also due to the multilingual nature of the state and the need to communicate. This is best seen in the tertiary institutions in the state, where students from diverse ethnic groups communicate in NP (Okon 2003). The NP has since become an elitist campus language.

\subsection{The Nigerian English (NE)}

The NE is a variant of English. Its use is done side by side with Standard English and like a variant is influenced by local indigenous languages. Most Nigerian English usage is based on direct translation, loan-blends and the influence of culture. The Nigerian English is widely used in Cross River with most people not overtly aware of the difference between Standard English and Nigerian English.

\section{Theoretical Framework}

As this work focuses primarily on the multilingual nature of Cross River State, we will use the rational choice model by Myers-Scotton (2002) as our theoretical framework. Myers-Scotton (2002) proposes that under this model, selection of choice of language is located within the individual not outside sources, based on the idea that choice will always be rational "when faced with several courses of action, people usually do what they believe is likely to have the best overall outcome", Elster (1979:22) as cited by Myers-Scotton (2002:206-207). Myers-Scotton proposes 3 filters through which speakers make rational choices. The first is 'external constraints' which include factors such as socio-economic status, gender, age and ethnicity. The second filter is 'internal constraints' including those of micro aspects of conversation that analysts argue are critical to understanding any conversation. The third filter, Myers-scotton calls 'rationality at work'. It is here that speakers make their code choices. Speakers consider their own and others' desires, values and beliefs, check those elements for internal consistency and consider likely outcomes of choices. In short, speakers make 'a cost-benefit analysis' (Myers-Scotton 2002:208).

\section{Language Typologies in Cross River State}

\subsection{The Mother-Tongue (MT/LI)}

According to Akindele and Adegbite (1992) a mother tongue is a language in which a bi or multilingual person has the 
greatest linguistic facility or intuitive knowledge and conducts his everyday activities. He uses the language both at formal and informal interactions. He understands the rules of pronunciation, syntax, lexis and discourse without having course to refer to texts for correct usage of these aspects of his/her mother tongue. The indigenous languages of Cross River State which number about 37 (Udoh 2003) are the mother tongue (MT/LI) of 2.89 million speakers. Of these languages (as in Table 1) there are 3 state languages of Efik, Bekwarra and Ejagham which have dominance and power over all the other indigenous languages as they are used not just in the media to disseminate news but also used to discuss relevant sociopolitical issues. The languages are also used in advertisement in the state media apparatus.

Other languages have power conferred on them by virtue of the fact that they have been raised in status to LGA languages and include languages such as Agwagune in Biase LGA, Lokaa in Yakurr LGA, Yala in Yala LGA, Mbembe in Obubra LGA, Bokyi on Boki LGA. Others are of fairly equal status to the surrounding languages in the LGA.

\subsection{The Second Language}

A second language (L2) can be defined as a language which is usually the sequentially second language of a bilingual person. For instance, in Cross River State, several languages vie for this position. They include the English language, herein referred to as Standard English (SE), the Nigerian Pidgin (NP), the Efik language in some LGAs such as Akamkpa and Biase LGAs. This is based on proximity and the dominance of the language in trade along the Cross River basin.

A second language is a variety in which a bi/multilingual person conducts the everyday activities but shares this role with another language in which the speaker has greater linguistic facility or intuitive knowledge. A second language is also a language that is learnt or acquired in a formal situation or education. It is also a variety which has its mother tongue standard variety modified by relevant local features. This could be applied to the Nigerian'dialect' of English otherwise known as Nigerian English. According to Crystal (2003) a second language is a language other than one's mother tongue used for a special purpose such as education, government etc. The major second language in Cross River State has varying degrees of power dominance. The English language in particular is the most powerful by virtue of the wider role it plays not just in Cross River State in particular but in Nigeria in general. These languages also have dual functions or even multiple functions. The Nigerian pidgin is not only popular, especially among the youths but it serves as a unifying factor in a pluralistic community as the state. It is particularly versatile with different variants (Ugot \& Offiong, 2013) and is widely spoken particularly in the Northern end of the state where there is a multiplicity of languages. The NP in the state is used for news, adverts and for socio-economic and political issues in the state media apparatus.

\subsection{Official Language}

An official language is described as a language used by the government for the conduct of business in the civil service, law, commerce, education and in all other official functions (Essien 2003). The official language is considered as a government oriented language. It may in some sense be an elitist language. In Cross River State, the official language is English as it is at the national level although at the national level other languages such as Igbo, Hausa, and Yoruba have the status of official and national languages. In the state, the English language is used as a medium of instruction and must be passed as a subject both in the junior secondary school level and senior secondary school certificate examination where it serves as one of the core subjects needed to enter a tertiary institution. According to Cummins (2006) in a world where knowledge of academic credentials in English are increasingly seen as the key to upward mobility and increased life chances both in the English-speaking world and internally, the assessment of English proficiency has become a game with very high stakes for both adults and school children.

\subsection{State and LGA Languages}

State and LGA languages can also be classified as regional languages as they are languages restricted to particular regions of the country. Such languages serve specific purposes such as education at the primary school level, interactions in trade and commerce within the defined region. The Efik language in capacity as a state and LGA language serves this purpose: it is used extensively for trade and commerce in LGAs form Calabar municipality, Calabar South, Akpabuyo, Bakassi, Odukpani, Akamkpa, Biase. Other regional minority languages like Efik which have come about from state creation include languages like Edo, Kanuri, Tiv, Ibibio etc.

The creation of state also raised the status of some languages to LGA language as they now have a function to play at the LGA headquarters but also because some now have the highest number of speakers in the LGA. 


\subsection{The Lingua Franca}

The lingua franca can be defined as a language which is used habitually by people whose mother tongues are different in order to facilitate communication between them (Todd 1978). It is a language of wider communication which is used in Cross-ethnic interaction. By this definition, the Nigerian Pidgin (NP) can be considered a lingua franca in Cross River State, as it cuts across ethnic boundaries and is mass oriented (Akindele \& Adegbite 1992). According to Holmes (2008) a pidgin arises where there are two groups with different languages communicating in a situation where there is a third dominant language. Again Holmes (2008) views a lingua franca as a language of communication between people with different mother tongues. A particular language could be used as a lingua franca as the need arises in a particular situation. More generally, the term lingua franca describes a language serving as a regular means of communication between different linguistic groups in a multi lingual speech community. Based on this definition, the Efik language and the Nigerian Pidgin also serve as lingua francas in Cross River State and thus have been raised further in status and power in the state. In terms of religion, the Efik language is the liturgical language while the NP is used widely for choruses in praise worship. (Ugot \& Offiong 2013)

\subsection{Trade Language}

Holmes (2008) insists that lingua francas develop mostly from trade languages, thus illustrating the influence of economic factors on language change. Thus languages like Hausa in West Africa, Swahili in East Africa were primarily trade languages. A trade language is a medium of communication that originated as a result of the development of trade and commerce. It is used specifically for the purpose of trade transactions. It may not be a mother tongue of any of the users. The NP and Efik are trade languages in Cross River State with the NP having a higher status as it is used right across the state while Efik is somewhat limited to going as far as the middle of the state to Biase LGA but pockets of communities further up also use Efik for some trade purposes.

\section{Language Choice in Cross River State}

\subsection{In Politics}

In politics, the NP is used at the grassroots level to reach the masses, particularly in an area where the speaker is not linguistically associated. To use SE would be considered as high-handedness and even a form of robbery. If one is speaking to people in his linguistic community, he may use his MT/LI. The media is also used for transmitting political issues and propaganda and NP is also used with SE for this purpose. For an appeal for people to come out and vote in an election, the media may use the state languages. NP, SE and also the three state languages are also used for advertisements, and propaganda.

\subsection{In Administration}

The predominant language for administration in Cross River State from the seat of government in Calabar to all other LGA headquarters is English. It is used as the official language and thus any 'serious business' such as administrative work is carried out in English. All formal documentation is done in English, even if the language used for interaction was an indigenous one.

\subsection{In Education}

English is the predominant language of education. The National Policy on Education NPE (2004) which stipulates that the child must be taught in the MT or language of the immediate environment (LIE) for the first three years in a primary school is not strictly adhered to in Cross River State. There are three basic reasons for this. One is that there are many private primary schools which adhere strictly to English as their medium of instruction, especially in the state capital Calabar and other large towns in the state. Secondly, with its multilingual nature, even where there is a dominant LIE language in use (such as Efik in Calabar) there are always children of other MT/LI who may not have grasped or acquired a mastery of the LIE to be taught in it. Thirdly, the option of developing the LIE with its literary materials for use in the primary schools poses a problem. However, this policy is only partly adhered to in government (public) schools. Private schools teach from pre-school in English and do not teach any of the indigenous languages as a subject. Some schools 
such as the secondary schools are run by Christian organizations and the medium of instruction is English and English is taught as a language alongside any choice of the individual student of any of the 3 national languages of Hausa, Yoruba and Igbo as stipulated in the NPE (2004). English is also the medium of instruction in all secondary and tertiary institutions in the state.

\subsection{In Social Interaction}

Okon (2003) avers that NP is the predominant language of socialization and is a language of effective communication in the state. It is acceptable by all regardless of one's status or education. English is used for formal interaction. The indigenous languages are used privately between individuals in family or group circles sharing the same linguistic background. The NP is very popular among youths even on university campuses. It is also used widely in music nationally and has thus caught on with local musicians or national musicians who hail from the state, (Ugot 2009).

\subsection{In Religion}

Cross River State is predominantly inhabited by Christians. In churches, one can clearly identify the Efik language as a language of liturgy in that the whole service could be conducted in Efik especially in southern Cross River State. However, in singing choruses which are simplistic songs used for praise worship the predominant language is the NP (Ugot \& Offiong, 2012). This runs right through the whole state without the limitations of the Efik language.

\section{Language Development and Language Death in Cross River State}

The Efik language had an orthography in the $19^{\text {th }}$ century and a full bible translation. Efik, Ejagham, Bekwarra and Yala have orthorgraphies. Out of this number, Efik is the highest on the scale. The other languages are underdeveloped because they have no orthorgraphies and no literary tradition (Udoh, 2003). However, oppression and neglect of their languages created a situation where language maintenance appeared to be a political tool of resistance to ethnic domination of small groups by large ones in Nigeria. Speakers of smaller languages as found in Cross River State began to take more pride in their own languages and a lot of effort is currently being put into developing their individual languages and instruments for developing orthographies are also being put in place.

Some languages in Cross River State have been threatened by assimilation by larger groups. For instance, the Akam language spoken by a small village between Ofutop and Ikom, forms a minority in an Ejagham speaking homogenous majority area. Ejagham and its dialects are spoken in this area, while Akam is a variety of Mbembe and may gradually become more like Ejagham by virtue of contact. Crozier \& Blench (1992) record three languages in Cross River State, all spoken in Odukpani and Akamkpa LGA's as becoming extinct. These are Kiong, Bakpinka and Odut. Kiong forms a cluster with Korop and Derop. Korop is not moribund but appears to be retreating. The Qua dialects of Ejagham spoken in Big Qua (Calabar) is gradually being assimilated by Efik. The Efut language spoken in Calabar South LGA is also threatened by Efik, as it is now moribund, spoken by only adults.

Although the fate of these languages depends very much on the political situation and government policies, it is apparent that government alone cannot cope with the problem of developing these languages. Only Efik, Bekwarra and Ejagham, the state languages are assured of institutional support.

\section{Language Empowerment and Cross River State Languages}

Cross River State languages are characterized by their status of minority or even micro-minority and this is due to their numerical strength of speakers. Their powerlessness in the wider Nigerian society includes;

1. Numerical paucity of less than 400,000 speakers for any of the languages.

2. Their domain of use is the home, and they are further affected by code-mixing, further disempowering the languages.

3. Most have no official or standard orthographies

Empowerment of such languages includes Essien's (1990) outline of basic steps of development to include;

a. Provision of a standard orthography acceptable to the generality of the native speakers of the language.

b. The production of primers for the primary school system

c. The compilation and publication of a dictionary for each of them.

d. The production of general literacy materials and creation of literacy tradition. 
e. Tradition of classics such as the Holy Bible in the language.

Other recommendations include the role to be played by government in approving the orthography officially and helping to fund the publication of primer series without which literacy in the targeted language would be impeded.

The people's attitude of the language is important as people are encouraged to use their language or else it will die or become assimilated by others.

\section{Conclusion}

This paper has examined the phenomenon of language and power in Cross River state. It has determined that the languages of the state are minority languages and proper language engineering has not been carried out on most of the languages. Status-wise, some languages such as Efik, Bekwarra and Ejagham have institutional support as they are state languages and are used for important things such as news dissemination. Others have limited powers within their LGAs by virtue of their numerical speakers and dominance in the LGAs. Others yet again though not indigenous to the state have even higher status and power in terms of usage. These include the English language as an official language and its variant, the Nigerian English; and the Nigerian Pidgin which is a language of interaction among the masses, a trade language, a second language and a lingua franca.

The Efik language is the most powerful of the state languages as it is widely used beyond its boundaries as a trade language, a second language, a lingua franca and has been well documented.

It has been suggested that proper corpus planning be done for the Cross River state languages so that they do not die as some are threatening to or be assimilated by stronger ones. Although political and economic imperatives tend to eliminate minority languages, such as those of Cross River State, it is important to remember examples like Welsh and Hebrew which demonstrate that languages can be maintained and even revived when a group values their distinct identity highly and regard language as a symbol of their identity, culture, history and heritage.

Also, in order to achieve the laudable objective of using the LIE in the earlier stages of education, there is need to outline a deliberate plan of action aimed at developing human capacity, orthographies, primers and learning materials for more languages in the state. This will confer power and further preserve the languages and cultures.

\section{References}

Abdullahi -Idiagbon, M.S. (2007). The Sociolinguistics of Nigerian Pidgin (English) on University campuses. In D. Adeyanju (ed). Sociolinguistics in the Nigerian context. Pp 201-216 Ile-Ife: Obafemi, Awolowo University Press.

Abegbija, E.E. (1994). The candidature of Nigerian Pidgin as a national language. Review of Applied linguistics Belgium.

Akindele F. \& Adegbite W. (1992). The Sociology and Politics of English in Nigeria: An Introduction. Ile-Ife: Obafemi Awolowo University Press

Bamgbose, A. (1992). Speaking in Tongues: Implication of multilingualism for Language Policy in Nigeria. Merit Award Winners Lecture Kaduna: The Board of Trustees of the Nigerian Merit Award.

Brann, C.M.B (1986). The role and function of Language in Government in Nigeria. (MIMEO)

Blench, R.M (2011). An Atlas of Nigerian Languages ( $3^{\text {rd }}$ Ed) Cambridge, UK: Kay Williamson Educational Foundation

Chomsky, N \& Halle, M (1968). Sound Pattern of English . New York:Harper and Row

Crozier, D.H \& Blench R.M (1992). An index of Nigerian Languages. Abuja:NERDC \& Dallas:SIL

Crystal, D (2003). A Dictionary of Linguistics and Phonetics. Oxford: Blackwell Publishing

Cummins, J. (2006). Language, Power and pedagogy: Bilingual children in the crossfire. Clevedon: Multilingual Matters Ltd.

Deutsche, K.W (1968). The trend of European nationalism. The Language Aspect. In Fishman, J.A (ed). Readings in the Sociology of Language. The Hague: Mouton

Enoh, A. O. (2013). The Neglect of Philosophy of Education and the Spread of Nigeria's Educational Wasteland. An Inaugural Lecture. Cross River University of Technology Calabar, Nigeria.

Essien, O.E (1990). The Future of Minority Languages. In Emenanjo, E.N (ed) Multilingualism, Minority Languages and Language Policy in Nigeria. Pp155-164 Agbor: Central Books Ltd.

Essien, O. E (2003a). Language and Power. An Inaugural Lecture. Faculty of Arts. University of Calabar, Calabar, Nigeria.

Essien O.E (2003b). The Minority Questions Re-visited. In Ndimele, M. O. (ed) Four Decades in the Study of Languages in Nigeria. A Festchrift for Kay Williamson pp 27-38. Aba: National Institute for Nigerian Languages (NINLA).

Essien, O.E (2003c). National Development, Language and Language Policy in Nigeria. In O.E Essien \& M. Okon (eds). Topical Issues in Sociolinguistics: The Nigerian Perspective Pp21-42.. Aba: NINLA

Federal Republic of Nigeria (2004). National Policy on Education. Lagos: NERDC

Garry, J and Rubino C (Eds) (2001), Facts about the world's languages: An Encyclopedia of the world's major languages: Past and Present. New York/Dublin: H. W. Wilson Press

Holmes, J (2008). An Introduction to Sociolinguistics. London: Pearson Longman 
Jowitt, D. (1991). Nigerian English Usage: An introduction. Lagos: Learn Africa Plc.

McGregor, W.B (2009). Linguistics: An Introduction. London: Cintinuum International Publishing Group.

Myers-Scotton, C (2002). Frequency and Intentionally in (un)Marked Choices in Code-Switching. 'This is a 24hr Country'. The International Journal of Bilingualism. 6 (2) 205-217

Nair, K (1972). Politics and Society in South Eastern Nigeria. 1841-1906. London:Frank Cass

National Population Commission (2010) 2006 Population and Housing census of the Federal Republic of Nigeria, Cross River State Priority Tables, Volume I.

Okon, B. A (2003). Communication and Social Reception of the Nigerian Pidgin in C.R.S. In O. Essien \& M. Okon (eds). Topical Issues in Sociolinguistics: A Nigerian Perspective. Aba: NINLA Pp 403-417

Olagoke, D. G (1982). Choosing a National Language for Nigeria. Journal of the Linguistic Association of Nigeria, JOLAN.I. 197-208

Peters, S.W (2000). Cross River State. In A. B Mamman, J.O Oyebanji and S.W. Peters (eds) Nigeria: A People United, a Future Assured, Survey of States. Vol 2. Pp121-132 Calabar: Gabumo Publishing Company Ltd

Sapir, E (1921). Language. New York: Harcourt Brace World

Skutnabb Kangas, T (1990). Language, Literacy and Minorities: A Minority Rights Group Report. London: Minority Rights Group.

Todd, L.C. (1984). Modern Englishes: Pidgins and Creo/es. Oxford: Basil Blackwell.

Udoh, I.I (2003). The Languages of Cross River State. In Udoh, I.I (Ed). The Languages of the South-South Zone of Nigeria: A GeoPolitical Profile. Pp51-69 Lagos: Concept Publications..

Ugot, M. (2009) Lexical Pidgin innovations in contemporary Nigerian popular music. Oniong: A contemporary Journal of Inter-Disciplinary Studies. 1 (1). 225-238.

Ugot, M., \& Offiong, O.A (2012). Sociolinguistic Survey, advancement of Indigenous Languages in Relationship to the Use of English Language in Southern Senatorial District of Cross River State, Nigeria. Research on Humanities and Social Sciences. 2 (7). 80 90.

Ugot, M., Offiong, O. A \& Oyo O.E (2013). Nigerian Pidgin Variations in the Ikom-Ogoja Axis of Cross River State, Nigeria. International Journal of Applied Linguistics \& English Literature. 2 (2) 223-230.

Ugot, M. \& Offiong, O.A (2013). Language and Communication in the Pentecostal Church of Nigeria. The Calabar Axis. Theory and practice in language studies 3(1) 148-154.

Wardhaugh, R. (1986). An introduction to sociolinguistics. Cambridge: Basil Blackwell Ltd.

Weinstein, B. (1980). Language Planning in Francophone Africa. Language Problem and language learning 4(1): 55-57. 